\title{
EXPERIENCE IN INFORMATIZATION OF MARITIME EDUCATION ABROAD
}

\section{ДОСВІД ІНФОРМАТИЗАЦІЇ МОРСЬКОЇ ОСВІТИ} ЗА КОРДОНОМ

\author{
Serhiy VOLOSHINOV, \\ Сергій волошИнов, \\ Candidate of Pedagogical Sciences, \\ Associate professor \\ https://orcid.org/0000-0001-9127-9999 \\ s_voloshinov@ukr.net \\ Kherson State Maritime Academy \\ Херсонська державна морська \\ академія \\ $\triangle 20$ Ushakov Avenue, \\ Kherson, Ukraine, 73000 \\ кандидат педагогічних наук, доцент \\ $\triangle$ проспект Ушакова, 20, \\ м. Херсон, Україна, 73000 \\ Revised manuscript accepted: December 11, 2019
}

\begin{abstract}
The article emphasizes the need to modernize the training of maritime professionals with the help of new information technologies. The urgency of the problem of improving the professional maritime education is conditioned by national and world trends in society in general and the maritime industry in particular. Most maritime education informatization studies are focused on analyzing and highlighting their own experience of implementing different types of ICTs into the professional training of future professionals. Therefore, analysis and generalization requires the issue of informatization of maritime education abroad. For this purpose, the study used such theoretical methods as analysis, induction, deduction, generalization in order to identify a positive experience in the informatization of maritime education, which can be used to improve the professional education of future maritime specialists. Based on the analysis of scientific works of foreign scientists on the informatization of maritime education, the following generalizations can be made. The fourth industrial revolution and the development of the information society are also affecting the maritime industry, which encourages the revision of the training of future maritime professionals, paying attention to the formation of their ICT competences. Foreign scientists propose the use of the following information technologies in maritime education: computer-based learning as the simplest form of e-learning; multi-user learning environment as a tool for creating virtual audiences and spaces; a three-dimensional virtual world of Second Life with elements of the social network as a platform for modeling gamified professional activity, cooperation and training; information communication technologies to support interaction with loved ones; Smart-education as an organization of education for the purpose of collective education in the World Wide Web; distance learning technologies as a tool for expanding the vocational education system.
\end{abstract}

Key words: computer science, maritime education, maritime professionals, information technology.

Вступ. Морська промисловість останнім часом зазнає проблем із наявністю висококваліфікованих фахівців. Важливо, що професійна 
Серія: Педагогічні науки. - Вип.3. - Бердянськ : БДПУ, 2019. - 453 с.

підготовка майбутніх морських фахівців $є$ найважливішим фактором для ефективної та продуктивної вітчизняної морської промисловості. Професійна підготовка $€$ найпотужнішим засобом для пом'якшення проблем, пов'язаних з компетентністю та якісним виконанням професійних обов'язків морськими фахівцями. На цьому тлі Міжнародна морська організація (International Maritime Organization - IMO) приділяла велику увагу потребі залучення, утримання та навчання кваліфікованих мореплавців. У Концепції стійкої системи морського транспорту (A concept of a Sustainable Maritime Transportation System) наголошується на тому, що важливою $є$ підвищення профілю морської освіти та перепідготовки (на березі та на судні) як поточних кар'єрних можливостей шляхом забезпечення їх адаптації до майбутніх проблем, включаючи інновації та еволюцію технології (IMO, 2013). Для підтримки успішності, впливовості та результативності морської галузі, що приваблює людей, здатних вивести галузь на наступний рівень, найважливішим є осучаснення професійної підготовки морських фахівців завдяки новим інформаційним технологіями.

Актуальність проблеми вдосконалення професійної морської освіти обумовлена національними і світовими тенденціями в суспільстві загалом та морській промисловості зокрема. Також вона зумовлена географічним й економічним факторами України та інтересом до розвитку морської галузі.

У зв'язку із розвитком інформаційного суспільства необхідна зміна парадигми в системі морської вищої освіти.

Проблеми інформатизації вищої освіти розглядалися такими науковцями, як В. Биков, В. Осадчий, С. Семеріков, О. Співаковський, Ю. Триус, В. Франчук та ін. Аналізу досвіду інформатизації вищої освіти за кордоном присвячено праці К. Годлевської, Н. Каменевої, А. Марчук, С. Памбук, А. Станкевич та ін. Питанням інформатизації морської освіти приділялася увага в дослідженнях О. Безбаха, О.Гудиревої, М. Кулакової, І. Сокола, М. Шермана, В. Чернікової та ін.

Під інформатизацією освіти В. Биков розуміє сукупність взаємопов'язаних організаційно-правових, соціально-економічних, навчально-методичних, науково-технічних, виробничих та управлінських процесів, спрямованих на задоволення інформаційних, обчислювальних і телекомунікаційних потреб (інших, пов'язаних із упровадженням методів і засобів інформаційно-комунікаційних технологій) учасників навчальновиховного процесу, а також тих, хто ним управляє та його забезпечує (у тому числі здійснює його науково-методичний супровід і розвиток) (Биков, 2010).

В. Осадчий, виходячи з нової парадигми вищої освіти, зауважує, що ії основу складає ідея інтегрованого інформаційного середовища закладу вищої освіти, розробки і використання сучасних інформаційних і педагогічних технологій, підтримки освітнього процесу шляхом інтеграції інформаційно-комунікаційних і педагогічних технологій, використання нового забезпечення - інформаційно-технологічного (Осадчий, 2013).

М. Кулакова, наголошує, що професійна підготовка $є$ керованим процесом, тому навчальною потребою в освіті $€$ перехід до застосування 
інформаційних технологій та їх засобів, які на основі управлінських дій дозволяють конструювати системи управління, що створюють умови для забезпечення широкого доступу до інформаційного простору й ефективного використання його можливостей (Кулакова, 2006).

Інформатизація процесу освіти, використання інформаційнокомунікаційних технологій (IКT) в освітньому процесі закладу вищої освіти (ЗВО), зокрема морського, повинні бути спрямовані, як свідчить О. Гудирева, на досягнення таких цілей: 1) збільшення ефективності всіх видів освітньої діяльності курсантів при використанні інформаційних і телекомунікаційних технологій; 2) підвищення якості професійної підготовки курсантів; 3) формування якісно нового мислення курсантів, що задовольняє умови інфрормаційного суспільства. Такий вплив інформатизації на цілі навчання спирається на потенційні можливості комп'ютера як засобу пізнавально-дослідницької діяльності курсанта, що забезпечує особистісно-орієнтований підхід до навчання, сприяє розвитку індивідуальних здібностей курсантів (Гудирева, 2011).

Більшість досліджень з інформатизації морської освіти спрямовані на аналіз та висвітлення власного досвіду впровадження різних типів ІКТ у процес професійної підготовки майбутніх спеціалістів. Тому аналізу та узагальнення вимагає питання інформатизації морської освіти закордоном.

Методи та методики дослідження. У дослідженні були використані такі теоретичні методи, як аналіз, індукція, дедукція, узагальнення з метою виявлення позитивного досвіду інформатизації морської освіти, що можуть бути використанні для вдосконалення професійної освіти майбутніх морських фахівців.

Результати та дискусії. Згідно з опитуванням IAMU (2018), важливість деяких компетентностей у профеесійній підготовці морських фахівців залишається майже незламною протягом 20 років. $€$ деякі компетентності, яким слід приділяти більше уваги в умовах сучасного інформаційного суспільства, зокрема ІКТ-грамотність. Також за результатами цього опитування найважливішими компетентностями сьогодні і за 5-10 останніх років $€$ технічна компетентність, технологічна обізнаність, навички обчислювальної техніки та інформатики (Tran, 2018).

Дійсно, технічна компетентність, як і раніше, відіграє найважливішу роль у галузі судноплавства. Ця компетентність стосується вмінь майбутніх морських фрахівців з експлуатації суден і в основному зосереджена на тому, як безпечно плавати на кораблях, а також ефективно використовувати бортове обладнання. Більшість умінь i навичок регламентовані Міжнародною конвенцією про стандарти підготовки і сертифікації моряків і несення вахти оновлюються відповідно до розвитку морської галузі та відповідних міжнародних морських правил.

Крім того, виникають потреби в технологічній обізнаності фахівців морської галузі, обчислювальній техніці та навичках з інформатики. Нині розвивається використання інноваційних технологій, що застосовуються в морській галузі, а далі їх кількість буде ще більше зростати. 
Судноплавна галузь також приділяє все більше уваги кібербезпеці, що пов'язано із використанням високотехнологічних пристроїв у галузі. Не так складно зрозуміти, чому ІКТ-компетентність $€$ важливою у професійній підготовці майбутніх морських фахівців.

Стосовно навичок обчислювальної техніки та інформатики, то вони вже не $\epsilon$ новою вимогою до підготовки моряків, оскільки були впроваджені з кінця $\mathrm{XX}$ століття разом із появою комп'ютерів. Більшість студентів сьогодні вже знають, як використовувати базове програмне забезпечення Microsoft Office Word або Excel для своєї роботи. Проте, в епоху 4-ї промислової революції, нового суспільства, в якому люди працюють, взаємодіють та живуть за допомогою цифрового вмісту та інструментів, ставиться більше вимог до ІКТ-навичок.

Основні уміння роботи за комп'ютером студенти морських вищих навчальних закладів отримують у школі або в морському коледжі. Викладач інформатики у ЗВО має дати більш глибокі знання предмета, i пояснити майбутнім морякам про необхідність вивчення інформатики для оперативного і правильного вирішення поставлених завдань і проблем, що виникають під час перебування на борту, для здійснення широкої і багатогранної діяльності в морській сфрері. Перш за все, до таких завдань можна віднести (Атрощенко, 2012):

1) ведення електронного документообігу, заповнення суднової ролі з використанням засобів будь-якого текстового редактора рідною й іноземною мовами;

2) розрахунок остійності судна як однієї 3 найважливіших морехідних якостей плавзасобу, а також графрічного представлення діаграми остійності;

3) забезпечення зв'язку не тільки внутрішнього, але і зовнішнього 3 застосуванням різних засобів зв'язку;

4) рішення адміністративних задач на судні;

5) робота з базами даних тощо.

Використання суднового комп'ютера зі встановленим спеціальним програмним забезпеченням $€$ невід'ємною частиною роботи моряка. Однак під час роботи за комп'ютером необхідно пам'ятати не тільки про безпеку мореплавання, а й комп'ютерну безпеку і знання законів, що стосуються правопорушень у сфері комп'ютерної інфрормації. Цифрові технології на флоті постійно розвиваються. Отже, процес професійної підготовки майбутніх моряків має ґрунтуватися на інфрорматизації морської освіти, що викликає необхідність у постійному підвищенні рівня їх ІКТ-компетентності як для успішної роботи, так і для безпеки пасажирів.

3 метою аналізу досвіду застосування інформаційних технологій у професійній підготовці майбутніх морських фахівців нами було здійснено аналіз закордонних наукових досліджень з цієї тематики і виділено позитивні аспекти різноманітних технологій.

A. Ibrahim та A. Tawfik виділили такі освітні технології в морській освіті, що базуються на інформаційних технологіях, як електронне навчання, тренажери, веб-навчання та комп'ютерне навчання. 
Комп'ютерно-орієнтоване навчання $(\mathrm{KOH})$ вважається найпростішою формою електронного навчання, що найчастіше використовується в морській галузі. Мобільність та незалежність КОН $€$ основними факторами його переваги над іншими технологіями та причиною їх широкого використання в морській галузі, особливо на борту кораблів, де їм віддають перевагу через дефіцит Інтернету. Проте КОН мають такий недолік, як старіння, зокрема якщо це стосується конвенцій IMO, які постійно оновлюються. Також бар'єрами для використання КОН $\epsilon$ недостатня комп'ютерна грамотність, відсутність інтересу до технологій, проблема з достовірністю оцінювання. На противагу цьому веборієнтовані технології можуть містити більший обсяг матеріалів, ніж звичайний DVD, а матеріали постійно доступні та оновлюються. Це полегшує роботу вчителя (якщо така $є$ ), дає змогу вдосконалювати методи викладання та збільшувати взаємодію тих, хто навчається, змушуючи їх відчувати себе під контролем, завдяки чому виробляється більш відповідальне ставлення до навчальної діяльності та збільшується ефеективність. Проте поганий доступ до Інтернету може бути проблемою, а також достовірність оцінювання (Ibrahim, Tawfik, 2015).

Організація Об'єднаних Націй з питань освіти, науки та культури (UNESCO) заявляє, що електронне навчання $є$ ключовим у забезпеченні технічної професійної освіти та навчання (TVET), а у системах морської освіти та навчання (MET), його потенціал поступово реалізується, низка шведських науковців (M. Kitada et al., 2017) розглядають його цінності та застосування в MET з точки зору відповідності теоріям навчання. У ході дослідження ними розроблено технологію багатокористувацького навчального середовища (MUVE) для підготовки мореплавців. За допомогою MUVE було створено дві віртуальні аудиторії, де студенти трьох різних закладів (Світового морського університету (Швеція), Університету транспорту Хошіміна (В'єтнам), Морського університету М'янми (М'янма)) брали участь у лекціях. Один віртуальний клас спрямований був на формування нетехнічних навичок, а інший технічних навички моряків.

Технологія MUVE описує стійке тривимірне графічне середовище, до якого можна отримати доступ через Інтернет та яке дозволяє користувачам одночасно в режимі реального часу взаємодіяти та спілкуватися (Salt, Atkins та Balckall, 2008). Користувач у MUVE в цифровому вигляді відображається через те, що називається аватаром, який є 3D графічним символом у MUVE і керується користувачем через користувальницький інтерфейс (клавіатура та миша). Ряд авторитетних закладів освіти, включаючи Гарвард і Масачусетський технологічний інститут, розробили освітні заходи з використанням технології MUVE. Вони виходять за межі та доповнюють, наприклад, електронні аудиторії, що використовують відеотехнології для створення спільних навчальних просторів шляхом упровадження виміру простору.

T. Pham у своєму дослідженні зазначає, що технологія MUVE реалізує діяльнісний підхід (“навчання дією"), оскільки за допомогою технологій 
електронного навчання можна вдосконалити професійну підготовку майбутніх морських фахівців. Адже навчання відбувається в умовах діяльності, коли людина намагається здійснити якісь значущі цілі і має подолати перешкоди на цьому шляху. Крім того, Т. Pham пов'язує застосування MUVE з соціальним навчанням на основі практики (Pham, 2012).

За такою технологією працює тривимірний віртуальний світ 3 елементами соціальної мережі Second Life. Це середовище визнано багатьма закладами освіти таким, що має значний потенціал для викладання та навчання (Second Life Education, 2019). Воно може сприяти навчанню різних дисциплін, наприклад, астрономія, медицина, хімія, історія, екологія, програмування, економіка, право, іноземна мова та ін. Здатність створювати складні середовища та об'єкти, відносно якісна графіка, можливість безкоштовного використання, багатство цікавих подій та можливість реалізувати навчання завдяки ігровій діяльності приваблюють як педагогів, так і студентів. Для входу у віртуальний світ потрібно завантажити безкоштовну програму «Second Life Viewer» i, зареєструвавшись на домашній сторінці, отримати доступ до віртуального світу за допомогою комп'ютера, що має підключення до Інтернету. У світі $€$ безліч способів для спілкування 3 іншими користувачами: текстові повідомлення, голосовий чат, вбудована програма електронного листування, невербальні комунікації (жести, рухи тіла, анімація та візуальна зовнішність персонажа).

Віртуальний світ Second Life пропонує функції, які підтримують подорожі. Користувач вибирає сітку-адресу і за допомогою миттєвого телепорту переміщається для участі в таких заходах, як дискусії, конференції, заняття, зустрічі тощо. Користувач також може шукати поточні події за допомогою опції фрільтрації пошуку, яка надає детальну інформацію про майбутні події та заходи всередині віртуального світу. Наприклад, можна шукати освітні заходи, організовані Відкритим університетом Великобританії (Pham, 2012).

Віртуальний світ підтримує багато сфер, починаючи від бізнесу, спілкування, співпраці, дозвілля, маркетингу до моделювання й освіти. Освітня мета віртуальної спільноти Second Life давно визнана завдяки використанню ігрової платформи. 150 закладів зареєструвались у Навчальному довіднику Second Life та офіційно створили свої віртуальні засоби. Такі освітні організації, як Консорціум нових медіа (NMC) та Міжнародне товариство технологій в освіті (ISTE) створили інфраструктуру всередині Second Life. Крім того, платформа також може надати простір для ряду (часто безкоштовних) освітніх заходів, таких, як конференції, лекції, інтерв'ю, дискусії та зустрічі.

Таким чином, використання MUVE дозволяє використовувати три основні компоненти, що разом або окремо можуть сприяти освітньому процесу: 1) MUVE як платформа для моделювання професійної діяльності у ігровій фрормі; 2) MUVE як платформа соціального співробітництва; 3) MUVE як метод віртуальної доставки навчального контенту. Межі між трьома компонентами є гнучкими, оскільки вони 
можуть дати можливість педагогам змішувати їх різними способами для сприяння навчальній діяльності на місцях або на відстані.

O.A. Bankole, V.V.M. Lalitha, H. U. Khan та A. Jinugu наголошують на важливості інформаційних технологій у професійній діяльності моряків СПГ-терміналів для підтримки спілкування. Адже робоче середовище моряка кваліфікується як ізольоване, а людина $є$ колективною істотою. Неможливість на борту судна підтримувати фізичну взаємодію із рідними і близькими впливає на робочі відносини. Такі поодинокі робочі середовища можна порівняти 3 космічними човниками, командами полярних експедицій тощо. Дослідження показали, що тривала робота в ізольованих умовах має психологічний вплив на відповідних осіб і потребує враховування (Bankole, Lalitha, Khan, Jinugu, 2017).

Ґрунтуючись на засадах 4-ї промислової революції T.Q. Le, визначає такі тенденції судноплавства 4.0, як Інтернет послуги на морі, робототехніка та автономія, кібербезпека, відкрита системна інтеграція, кібер-фрізика, аналітика даних, доповнена реальність, симулація та оптимізація (Le, 2019). Тому B'єтнамський морський університет (Vietnam Maritime University), окрім визначення профеесійних та профеесійних стандартів випускників, приділяє особливу увагу вивченню інфрормаційних технологій.

Нині залишається актуальним питання пошуку таких стратегій навчання, які пов'язані як з ефективним використанням інформаційних і комунікаційних технологій, так і навчанням та вихованням молодої, креативної і творчої особистості. Таким на думку деяких науковців (V. Uskov, R. Howlett, L. Jain, Б. Кубеков, Д. Плотніков), виступає парадигма Smart-освіти, що передбачає гнучкість, яка припускає наявність великої кількості джерел, максимальну різноманітність мультимедіа, здатність швидко і просто налаштовуватись під рівень i потреби слухача. Вона також передбачає активний обмін досвідом та ідеями, персоніфікацію курсу залежно від його завдань і компетенцій суб'єктів навчання (Стопчак, Чорна, 2014).

Smart-освіта - це організація освіти і профресорсько-викладацького складу з метою виконання колективної освітньої діяльності у всесвітній мережі, яка була заснована на базі загальних еталонів, угод і технологій. Концепцією Smart-освіти $€$ адаптивність, яка передбачає наявність значної кількості джерел, великої кількості мультимедійних засобів (аудіо, відео, графріка), вміння швидко і точно підлаштовуватися під рівень і запити аудиторії. Разом із тим Smart-освіта повинна бути легко і вільно керованою, для того, щоб освітня організація могла легко забезпечувати адаптивність освітнього процесу. Також Smart-освіта ґрунтується на гнучкому навчанні в інтерактивному освітньому середовищі за допомогою інформації з усіх частин світу, яка знаходиться у відкритому доступі. Ключовим її поняттям є доступність у будь-якому місці. Вона являє собою систему, яка передбачає широке удосконалення всіх освітніх дій, включаючи методики і технічну спрямованість, які використовуються в цих діях. За допомогою доктрини Smart, в освіті відбувається поширення 
технологій, таких, як розумна дошка, розумні екрани, доступ до Інтернет з будь-якої точки світу. Будь-яка 3 перерахованих технологій дає можливість по-іншому зробити процес підготовки інформації, його доступності та актуалізації. Основою для процесу освіти стає активний контент, на базі якого створюються єдині репозиторії, які дозволяють прибрати перешкоди в часі і просторі (Кубеков, Плотников, 2018).

Нині залишається в пріоритеті застосування дистанційних технологій у професійній підготовці майбутніх морських фахівців, що розглядається як провідний інструмент для розширення системи професійної освіти, як один із засобів зменшення витрат і підвищення можливості отримання освіти широкими верствами населення. Тому для забезпечення потреб держави, роботодавців і громадян в отриманні якісної освіти за затребуваними програмами підготовки та національне законодавство в галузі освіти і Конвенція ПДНВ спрямовують освітні організації на використання в організації та реалізації освітнього процесу дистанційних технологій та електронного навчання (Тарануха, 2015).

Висновки. На основі аналізу наукових праць закордонних науковців щодо інформатизації морської освіти можна зробити такі узагальнення. Четверта промислова революція і розвиток інформаційного суспільства впливає і на морську галузь, що спонукає до перегляду професійної підготовки майбутніх морських фахівців, звертаючи увагу на формування їх ІКТ-компетентності. Зарубіжні науковці пропонують застосування таких інформаційних технологій у морській освіті: комп'ютерно-орієнтоване навчання як найпростіша фрорма електронного навчання; багатокористувацьке навчальне середовище як засоби для створення віртуальних аудиторій і просторів; тривимірний віртуальний світ 3 елементами соціальної мережі як платформа для моделювання професійної діяльності в ігровій формі, співробітництва та навчання; інформаційні технології спілкування для підтримки взаємодії з рідними і близькими; Smart-освіта як організація освіти 3 метою виконання колективної освітньої діяльності у всесвітній мережі; дистанційні технології навчання як інструмент для розширення системи професійної освіти.

Перспективи подальших досліджень вважаємо доцільним спрямувати на пошук шляхів впровадження окреслених інформаційних технологій у професійну підготовку майбутніх морських фрахівців в Україні.

\section{Література}

1.Bankole O.A. Information technology in the maritime industry past, present and future: focus on Ing carriers / O.A.Bankole, V.V.M. Lalitha, H.U. Khan, A. Jinugu // 7th International Advance Computing Conference (IACC). - 2017. - P. 759-763.

2. Ibrahim A. M. Educational technology in MET simulator based training and information technology in ME / A.M. Ibrahim, A.K. Tawfik // International Journal of Mechanical Engineering. - 2015. - № 4(3). - C. 1-10.

3. IMO. World maritime day, a concept of a sustainable maritime transportation system [Електронний ресурс]. - Режим доступу: URL: http://www.imo.org/en/MediaCentre/HotTopics/SMD/Pages/default.aspx.

4.Kitada M.. Learning theories meet virtual classroom technologies: understanding new educational opportunities in maritime education and training. / $\mathrm{M}$. 
Kitada, J. Bolmsten, K. Zeya, T.H. Pham, M.S. Aung, // Global perspectives in MET: Towards Sustainable, Green and Integrated Maritime Transport. - 2017. - 1. - P. 72-81.

5.Le T.Q. Approaching CDIO to Innovate the Training Program for Seafarers to Meet the Requirements of the Industrial Revolution 4.0 / T. Q Le // International Journal on Advanced Science, Engineering and Information Technology. - 2019. - № 9 (2). C. 648- 655 .

6.Meyers E. M.. Digital literacy and informal learning environments: an introduction / E.M. Meyers, I. Erickson, R.V. Small // Learning, media and technology. 2013. - № 38(4). - P. 355-367.

7.Pham T.H. Virtual MET Institution: Assessing the potentials and Challenges of Applying Multi-User Virtual Environment in Maritime Education and Training : MSc dissertation / Trong Hieu Pham. - Malmö: World Maritime University. 2012. - 99 p.

8.Salt B., Atkins C., Balckall L.. Engaging with Second Life: Real education in a virtual world. - 2008 - P. 99. [Електронний ресурc]. - Режим доступу : URL: http://piensl.pbworks.com/f/slliteraturereviewa1.pdf.

9.Second Life Education Directory [Електронний ресурс]. - Режим доступу : URL: http://wiki.secondlife.com/wiki/Second_Life_Education_Directory.

10. Tran T.N.M. Integrating requirements of Industry 4.0 into maritime education and training: case study of Vietnam : MSc dissertation / Thi Nguyet Minh Tran. - Malmö: World Maritime University. - 2018. - P. 84.

11. Атрощенко Е.А. ИКТ-компетентность будущих моряков / Е.А. Атрощенко // XIX Научная конференция «Современные информационные технологии: тенденции и перспективы развития» (Ростов-на-Дону, 16-19 мая 2012 г.) : материалы конференции. - Ростов-на-Дону, 2012. - С. 30-31.

12. Биков В.Ю. Сучасні завдання інформатизації освіти / В. Ю. Биков // Інформаційні технології і засоби навчання. - 2010. - №1(15). - [Електронний peсурс]. - Режим доступу : URL: http://journal.iitta.gov.ua/ index.php/ittt/article/view/25/13.

13. Гудирева О.М. Впровадження ІКТ при викладанні математики у морському вузі / О.М. Гудирева // Інформаційні технології в освіті. - 2011. - Вип. 10. - С. 64-72.

14. Кубеков Б.С. Организация информационного пространства образовательной системы в условиях Smart-образования / Б.С. Кубеков, Д.Д. Плотников. - 2018. [Електронний ресурc]. - Режим доступу : URL: http://www.bntu.by/images/stories/mido/ntik6/kubp.pdf.

15. Кулакова М.В. Формування готовності до професійної діяльності в майбутніх фахівців у вищих морських навчальних закладах : дис. ... канд. пед. наук : 13.00.04 / Майя Володимирівна Кулакова. - Одеса, 2006. - 248 с.

16. Осадчий В.В. Система інформаційно-технологічного забезпечення професійної підготовки майбутніх учителів в умовах педагогічного університету : дис. ... д-ра пед.. наук : 13.00.04 / Вячеслав Володимирович Осадчий. - Вінниця, 2013. - 559 c.

17. Стопчак M. SMART-освіти: сутність, тенденції розвитку, шляхи реалізації в Україні / М. Стопчак, Н.Чорна // Smart-освіта: ресурси та перспективи : матеріали Міжнар. наук.-метод. конф. (Київ, 16-17 жовтня 2014 р.) : тези доповідей. - К.: Київ. нац. торг.-екон. ун-т, 2014. - С. 261-263.

18. Тарануха С.Н.. Дистанционные образовательные технологии в системе качества подготовки членов экипажей судов / С.Н. Тарануха // Вестник государственного университета морского и речного фрлота им. адмирала С.О. Макарова. - 2015. - № 4(32). - С. 216-222. 
Серія: Педагогічні науки. - Вип.3. - Бердянськ : БДПУ, 2019. - 453 с.

\section{References}

1. IMO. (2013). World maritime day, a concept of a sustainable maritime transportation system.rom http://www.imo.org/en/MediaCentre/HotTopics/SMD/Pages/default.aspx [in English].

2. Kulakova, M.V. (2006). Formuvannia hotovnosti do profesiinoi diialnosti v maibutnikh fakhivtsiv u vyshchykh morskykh navchalnykh zakladakh [Development of the future specialists' readliness to professional activity at higher marine educational establishments] (PhD thesis). South-Ukrainian State Pedagogical University named after K.D. Ushinsky, Odessa [in Ukrainian].

3. Osadchyi, V.V. (2013), Systema informatsiino-tekhnolohichnoho zabezpechennia profesiinoi pidhotovky maibutnikh uchyteliv $v$ umovakh pedahohichnoho universytetu [The system of informational and technological support for the training of future teachers in the conditions of a pedagogical university], Doctoral thesis, Vinnytsia State Pedagogical University named after Mykhailo Kotsiubynsky, Vinnytsia, 419 p. [in Ukrainian].

4. Bykov, V. (2010). Suchasni zavdannia informatyzatsii osvity [Modern tasks of infomatization of education]. Information Technologies and Learning Tools, 1(15). Retrieved from http://journal.iitta.gov.ua/ index.php/ittl/article/view/25/13 [in Ukrainian].

5. Hudyreva, O.M. (2011). Vprovadzhennia IKT pry vykladanni matematyky $u$ morskomu vuzi [Implementation of ICT in teaching mathematics at the maritime university]. Information technology in education, Vol. 10, 64-72 [in Ukrainian].

6. Le, T.Q. (2019). Approaching CDIO to Innovate the Training Program for Seafarers to Meet the Requirements of the Industrial Revolution 4.0. International Journal on Advanced Science, Engineering and Information Technology, 9 (2), 648- 655 [in English].

7. Bankole, O.A., Lalitha, V.V.M., Khan, H.U. \& Jinugu, A. (2017). Information technology in the maritime industry past, present and future: focus on Ing carriers, 7th International Advance Computing Conference. Hyderabad, India : IEEE [in English].

8. Ibrahim, A.M., \& Tawfik, A.K. (2015). Educational technology in MET simulator based training and information technology in MET. International Journal of Mechanical Engineering, 4(3), 1-10 [in English].

9. Kitada, M., Bolmsten, J., Zeya, K., Pham, T. H., \& Aung, M. S. (2017). Learning theories meet virtual classroom technologies: understanding new educational opportunities in maritime education and training. Global perspectives in MET: Towards Sustainable, Green and Integrated Maritime Transport, 1, $72-81$ [in English].

10. Salt, B., Atkins, C., \& Balckall, L. (2008). Engaging with Second Life: Real education in a virtual world. Retrieved from http://piensl.pbworks.com/f/slliteraturereviewa1.pdf [in English].

11. Pham, T.H. (2012). Virtual MET Institution: Assessing the potentials and Challenges of Applying Multi-User Virtual Environment in Maritime Education and Training (MSc dissertation). World Maritime University, Malmö [in English].

12. Stopchak, M., \& Chorna, N. (2014). SMART-osvity: sutnist, tendentsii rozvytku, shliakhy realizatsii $v$ Ukraini [SMART-education: essence, tendencies of development, ways of realization in Ukraine]. Smart-osvita: resursy ta perspektyvy [Smart Education: Resources and Perspectives], International Scientific and Methodological Conference, 2014 October 16-17, Kyiv: Kyiv National University of Trade and Economics, 261-263. [in Ukrainian].

13. Kubekov, B.S.. \& Plotnikov, D.D. (2018). Organizatsiya informatsionnogo prostranstva obrazovatelnoy sistemy $v$ usloviyakh Smart-obrazovaniya [Organization of the information space of the educational system in the conditions of Smart-education]. Retrieved from http://www.bntu.by/images/stories/mido/ntik6/kubp.pdf. [in Russian]. 
14. Tran, T.N.M. (2018). Integrating requirements of Industry 4.0 into maritime education and training: case study of Vietnam (MSc dissertation). World Maritime University, Malmö. [in English].

15. Meyers, E. M., Erickson, I., \& Small, R. V. (2013). Digital literacy and informal learning environments: an introduction. Learning, media and technology, 38(4), 355-367. [in English].

16. Atroshchenko, E.A. IKT-kompetentnost budushchikh moryakov [ICT competence of future sailors]. XIX Scientific Conference "Modern Information Technologies: Trends and Prospects of Development», 2012 May 16-19, Rostov-onDon, 30-31 [in Russian].

17. Second Life Education Directory (2019). Retrieved from http://wiki.secondlife.com/wiki/Second_Life_Education_Directory. [in English].

18. Taranukha, S.N. (2015). Distantsionnyye obrazovatelnyye tekhnologii v sisteme kachestva podgotovki chlenov ekipazhey sudov [Distance education technologies in the quality management system of training seafarera]. Vestnik gosudarstvennogo universiteta morskogo i rechnogo flota imeni admirala S.O. Makarova, 4(32), 216-222. [in Russian].

\section{АНОТАЦІЯ}

У статті наголошується на потребі осучаснення профресійної підготовки морських фрахівців завдяки новим інформаційним технологіями. Актуальність проблеми вдосконалення професійної морської освіти обумовлена національними і світовими тенденціями в суспільстві загалом та морській промисловості зокрема. Більшість досліджень з інформатизації морської освіти спрямовані на аналіз та висвітлення власного досвіду впровадження різних типів інфрормаційно-комунікаційних технологій (IКT) у процес професійної підготовки майбутніх спеціалістів морської галузі. Тому аналізу та узагальнення вимагає питання інформатизації морської освіти закордоном. 3 иією метою у дослідженні були використані такі теоретичні методи як аналіз, індукція, дедукція, узагальнення з метою виявлення позитивного досвіду інформатизації морської освіти, що можуть бути використанні для удосконалення профресійної освіти майбутніх морських фрахівців. На основі аналізу наукових праць сучасних закордонних науковців щодо інфоорматизації морської освіти можна зробити такі узагальнення. Четверта промислова революція і розвиток інформаційного суспільства впливає і на морську галузь, що спонукає до перегляду профресійної підготовки майбутніх морських фахівців, звертаючи увагу на формування їх IKT-компетентності. Зарубіжні науковці пропонують застосування таких інформаційних технологій у морській освіті: комп'ютерно-орієнтоване навчання як найпростіша форма електронного навчання; багатокористувацьке навчальне середовище як засоби для створення віртуальних аудиторій та просторів; тривимірний віртуальний світ Second Life з елементами соціальної мережі як платформа для моделювання професійної діяльності у ігровій фрормі, співробітництва та навчання; інфрормаційні технології спілкування для підтримки взаємодії з рідними та близькими; Smartосвіта як організація освіти з метою виконання колективної освітньої діяльності у всесвітній мережі; дистанційні технології навчання як інструмент для розширення системи профресійної освіти майбутніх морських фрахівців.

Ключові слова: інформатизація, морська освіта, морські фрахівці, інформаційні технологї. 